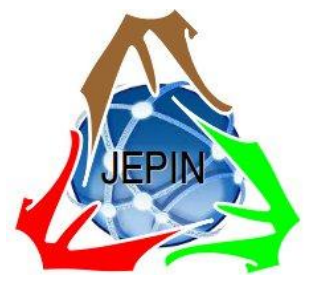

JEPIN

\title{
Perbandingan Model Klasifikasi untuk Evaluasi Kinerja Akademik Mahasiswa
}

\author{
Rinna Rachmatika ${ }^{\# 1}$, Achmad Bisri ${ }^{\# 2}$ \\ \#Program Studi Teknik Informatika, Universitas Pamulang \\ Jl. Raya Puspiptek, Buaran, Kec. Pamulang, Kota Tangerang Selatan, Banten 15310 \\ ${ }^{1}$ rinnarachmatika@unpam.ac.id \\ ªchmadbisri@unpam.ac.id
}

\begin{abstract}
Abstrak - Dunia pendidikan saat ini mengalami kompetisi yang begitu ketat, terutama pada era digital seperti saat ini, dimana salah satunya yaitu pendidikan tinggi yang saling berkompetisi dalam meraih peringkat terbaik. Instrumen dalam dunia pendidikan seperti penerimaan mahasiswa baru hingga kelulusan dapat dievaluasi berdasarkan kinerja mahasiswa agar terwujudnya pendidikan yang berkualitas. Pengambilan keputusan dalam evaluasi kinerja akademik mahasiswa pada kelulusan tepat waktu dan tidak tepat waktu dapat dilakukan dengan penambangan data pendidikan (educational data mining). Berbagai model klasifikasi data mining pada pendidikan telah banyak dilakukan para peneliti. Namun, secara umum sulit untuk menentukan model klasifikasi terbaik dari berbagai metode pada evaluasi kinerja akademik mahasiswa dengan kasus yang sama. Tujuan dari penelitian ini untuk menentukan model klasifikasi yang memiliki kinerja terbaik pada prediksi kelulusan mahasiswa tepat waktu yang dievaluasi berdasarkan empat dataset yaitu TI-Reg.A, TI-Reg.B, AK-Reg.A, dan AK-Reg.B. Indikator dalam evaluasi kinerja model berdasarkan peringkat ratarata akurasi. Hasil eksperimen menunjukkan bahwa model klasifikasi random forest memiliki kinerja terbaik pada sebagian dataset dan memiliki nilai akurasi rata-rata peringkat tertinggi dibandingkan model GBT. Sedangkan, model DT, NB, $k$-NN, LR, NN, MLP, dan SVM memiliki kinerja yang sama baik.
\end{abstract}

Kata kunci- Educational Data Mining, Klasifikasi, Akademik, Kelulusan, Prediksi.

Abstract - The world of education is currently experiencing intense competition, especially in the current digital era. Where higher education competes with each other to achieve the best rank. Instruments in the world of education, such as the admission of new students to graduation can be evaluated based on university student academic performance in order to realize quality education. Decision making, using the evaluation of university student academic performance in predicting graduation on time can be done with educational data mining. Various data mining, classification models in education have been carried out by many researchers. However, it is generally difficult to determine the best classification model from various methods in evaluating university student academic performance with the same case. The purpose of this study is to determine the classification model that has the best performance in predicting student graduation on time, which is evaluated based on four datasets, namely TI-Reg.A, TI-Reg.B, AK-Reg.A, and AK-Reg.B. Indicators in the evaluation of model performance are based on accuracy average rank. The experimental results show that the random forest classification model has the best performance of a portion of the dataset and has the highest average accuracy rank compared to the GBT model. Meanwhile, the DT, NB, k-NN, LR, NN, MLP, and SVM models have the same good performance.

Keywords - Educational Data Mining, Classification, Academic, Graduation, Prediction.

\section{Pendahuluan}

Educational data mining (EDM) adalah pengembangan model yang dapat mengeksplorasi data-data yang berasal dari konteks pendidikan untuk meningkatkan kinerja pendidikan [1]. EDM dapat disimpulkan sebagai gabungan disiplin ilmu komputer, statistik, dan pendidikan yang menggunakan teknik data mining untuk mengubah data menjadi informasi dan pengetahuan yang berguna.

Kompetisi dalam dunia pendidikan begitu ketat pada era digital dalam meraih peringkat terbaik. Berbagai hal dalam dunia pendidikan mulai dari penerimaan mahasiswa baru hingga kelulusan dan evaluasi kinerja mahasiswa merupakan instrumen yang harus dilakukan agar terwujudnya pendidikan yang baik dan memenuhi standar pendidikan. Pendidikan tinggi dengan jumlah mahasiswa yang besar perlu memperhatikan kinerja mahasiswa baik dari penerimaan mahasiswa baru sebagai input maupun lulusan mahasiswa sebagai output. Pengambilan keputusan dalam evaluasi kinerja mahasiswa dapat dilakukan dengan penambangan data pendidikan (educational data mining).

Penelitian pada bidang EDM telah banyak dilakukan dengan berbagai teknik data mining yang kemudian dilakukan pemodelan dengan model pembelajaran mesin (machine learning) untuk mengekstrak informasi secara otomatis yang melibatkan data latih (training) dan uji (testing), sehingga dapat mengevaluasi maupun memprediksi hasil di masa mendatang. Sulitnya 
menentukan model klasifikasi terbaik dari sembilan metode membuat peneliti mencoba menganalisisnya. Beberapa model klasifikasi seperti gradient boosted trees untuk menentukan kelulusan tepat atau tidak tepat waktu dalam menangani masalah ketidakseimbangan kelas [2], kemudian penelitian dengan menggunakan metode klasifikasi decision tree dan adaboost [3]. Metode naive bayes, metode yang mudah dipahami dan juga menjadi pilihan bagi peneliti untuk membuat prediksi. Naïve bayes dan neural network digunakan untuk prediksi masa studi mahasiswa [4] dengan sampel mahasiswa yang lulus dan drop-out. Dalam penelitian yang memberikan gambaran tentang teknik data mining yang telah digunakan untuk memprediksi kinerja siswa, algoritma prediksi dapat digunakan untuk mengidentifikasi atribut yang paling penting dalam sebuah data siswa sehingga memberikan manfaat bagi siswa, pendidik dan institusi [5]. Dunia pendidikan saat ini berkembang pesat karena banyaknya informasi siswa yang dapat digunakan untuk menemukan pola yang berharga yang berkaitan dengan perilaku belajar siswa. Institusi pendidikan dapat memanfaatkan pendidikan data mining untuk mengetahui kinerja siswa yang dapat mendukung institusi dalam mengakui kinerja siswa [6]. Mengukur kinerja akademik siswa merupakan tantangan karena kinerja akademik siswa bergantung pada berbagai faktor [7]. Educational data mining, melibatkan algoritma dengan teknik statistik untuk membantu menginterpretasikan kinerja akademis siswa [8]. Tujuan utama perguruan tinggi adalah memberikan pendidikan yang berkualitas kepada para mahasiswanya. Salah satu cara untuk mencapai tingkat kualitas tertinggi adalah dengan mengidentifikasi faktor-faktor yang mempengaruhi kinerja akademik mahasiswa berdasarkan pola dalam data yang tersedia (catatan siswa dan kursus) yang dapat berguna untuk memprediksi kinerja siswa [9]. Data Mining telah banyak digunakan untuk memprediksi kinerja siswa, dalam penelitian [10] dilakukan seleksi fitur untuk menyeleksi atribut yang berpengaruh tinggi terhadap kinerja mahasiswa Jurusan Teknik Industri Universitas Islam Indonesia.

Pada penelitian ini, kami mengusulkan sembilan metode machine learning yang populer sebagai model klasifikasi yaitu decision tree (DT), support vector machine (SVM), neural network (NN), naïve Bayes (NB), gradient boosted trees (GBT), random forest (RF), logistic regression (LR), $k$-nearest neighbors $(k-\mathrm{NN})$, auto multilayer perceptron (MLP). Dari sembilan model klasifikasi yang memiliki kinerja terbaik akan dipilih sebagai solusi terhadap evaluasi kinerja akademik mahasiswa. Tujuan dari penelitian ini, untuk mengidentifikasi model yang memiliki kinerja terbaik pada evaluasi kinerja akademik mahasiswa berdasarkan dengan dataset kelulusan.

\section{METODE}

Secara sistematis penelitian ini dibagi ke dalam beberapa tahapan penelitian yaitu, yakni mengumpulkan data, dilanjutkan dengan mengolah data, lalu usulan model klasifikasi, kemudian melakukan eksperimen dan pengujian, dan pada tahap akhir dilakukan evaluasi dan model dilakukan tahap validasinya, seperti yang ditunjukkan dalam Gambar. 1 yaitu Tahapan Penelitian.

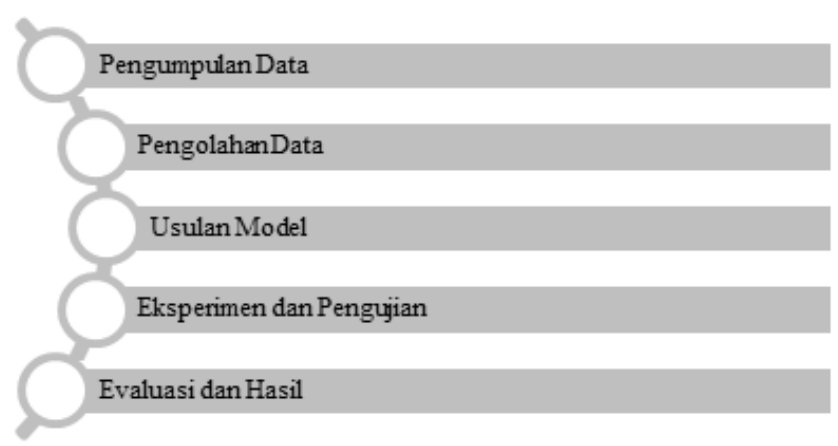

Gambar. 1 Tahapan penelitian

\section{A. Tahapan Pengumpulan Data}

Dalam tahapan pertama ini, peneliti melakukan pengumpulan data mentah yang akan diproses, dimana data tesebut peneliti peroleh dari IT Centre Universitas Pamulang dan data tersebut bersifat khusus. Data yang di dapatkan adalah data akademik program studi, fakultas dan data mahasiswa yang diambil dari lulusan tahun 2017/2018 Universitas Pamulang.

\section{B. Tahapan Pengolahan Data}

Pada proses ini, peneliti mengolah seluruh data dari hasil yang sudah dikumpulkan dengan melakukan data cleaning atau pembersihan data guna mengatasi masalah yang biasa ditemukan seperti nilai yang tidak ada, anomaly, data tidak sesuai atau adanya redundansi atau pengulangan data. Setelah itu, data dikelompokkan lalu dipilah sesuai dengan jenis dan fungsinya untuk di distribusikan ke dalam data testing dan training, lalu diterapkan didalam modelmodel klasifikasinya. Dari hasil pengolahan data, didapat sebesar 1174 instance, yang menunjukkan datasets akademik prodi Teknik Informatika dan Akuntansi yang dibagi dalam Reguler A dan B, ditunjukkan pada Tabel I.

TABEL I

DatASETS Kelulusan

\begin{tabular}{|c|c|c|c|}
\hline Dataset & Tepat & Tidak & Jml \\
\hline TI-Reg.A & 139 & 233 & 372 \\
\hline TI-Reg.B & 79 & 194 & 273 \\
\hline AK-Reg.A & 22 & 200 & 222 \\
\hline AK-Reg.B & 32 & 275 & 307 \\
\hline
\end{tabular}




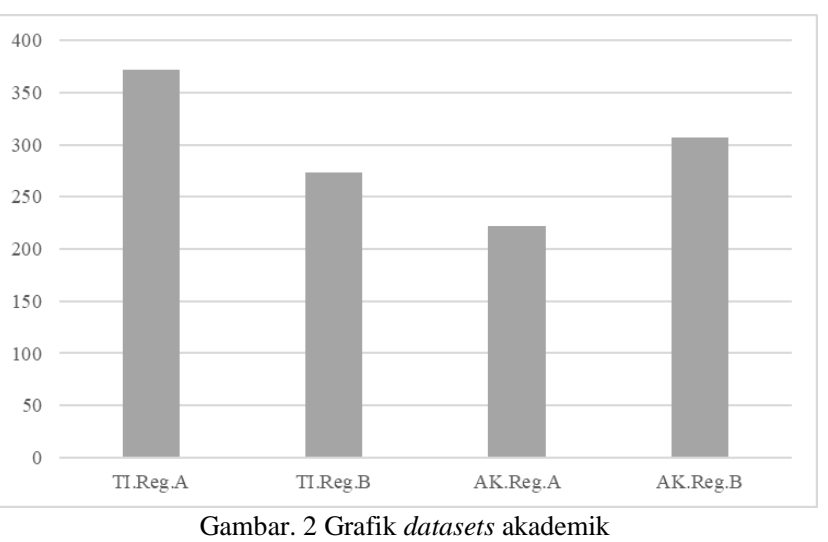

TABEL III

KARAKTERISTIK DATASETS KELULUSAN

\begin{tabular}{|c|c|c|}
\hline No & Fitur & Keterangan \\
\hline 1 & Umur & Umur Mahasiswa \\
\hline 2 & JK & Jenis Kelamin \\
\hline 3 & Reg. & Reguler Shift \\
\hline 4 & IPS1 & IP Semester 1 \\
\hline 5 & IPS2 & IP Semester 2 \\
\hline 6 & IPS3 & IP Semester 3 \\
\hline 7 & IPS4 & IP Semester 4 \\
\hline 8 & IPS5 & IP Semester 5 \\
\hline 9 & IPS6 & IP Semester 6 \\
\hline 10 & Label & Class (Tepat atau Tidak) \\
\hline
\end{tabular}

Tabel I adalah dataset berdasarkan kinerja akademik dari Prodi Teknik Informatika dan Akuntansi Reguler A dan B yang sudah melalui proses pengolahan. Gambar.2 merupakan gambar grafik datasets akademik yang didapatkan dari hasil pengolahan. Tabel II adalah bentuk dari karakteristik dataset akademik yang digunakan untuk membuat model atau metode klasifikasi pada evaluasi kinerja mahasiswa yaitu, umur, lalu jenis kelamin (JK), lalu diambil dua program studi yaitu prodi Teknik Informatika Strata 1 dan Prodi Akuntansi Strata 1, lalu jenis kelas reguler yang terdiri dari reguler A dan B, dan IPS (Indeks Prestasi Semester) dari semester awal (satu) hingga semester enam, dengan status kelulusan mahasiswa yang tepat waktu lulusnya dan tidak tepat waktu sebagai sebuah label atau class.

\section{Usulan Model}

Pada Gambar.3, model yang diusulkan terdiri dari sembilan metode yaitu decision tree (DT), support vector machine (SVM), neural networks (NN), naïve Bayes (NB), gradient boosted trees (GBT), random forest (RF), logistic regression (LR), $k$-nearest neighbors $(k-\mathrm{NN})$, auto multilayer perceptron (MLP), yang mampu melakukan pemodelan klasifikasi. Dari proses pengumpulan data, kemudian data yang diperoleh dilakukan pre-processing yaitu proses cleaning data dan preparing sebelum data ditransformasikan sebagai data training yang selanjutnya akan diterapkan pada sembilan metode klasifikasi dengan 10 fold cross-validation, dimana total data trainingnya ada (satu) bagian dijadikan data uji coba (testing) dan ada (sembilan) bagian yang lain dijadikan sebagai data latihan (training), dan proses tersebut dilakukan berulang secara bergantian hingga mendapat nilai hasil secara keseluruhan sehingga dapat di ambil nilai rata-ratanya. Hasil dari model klasifikasi yang dibangun akan dilakukan proses pengujian dengan beberapa sampel yang telah dibagi sebagai testing. Dari sembilan model akan dilakukan perbandingan dengan mengukur tingkat keakuratannya.

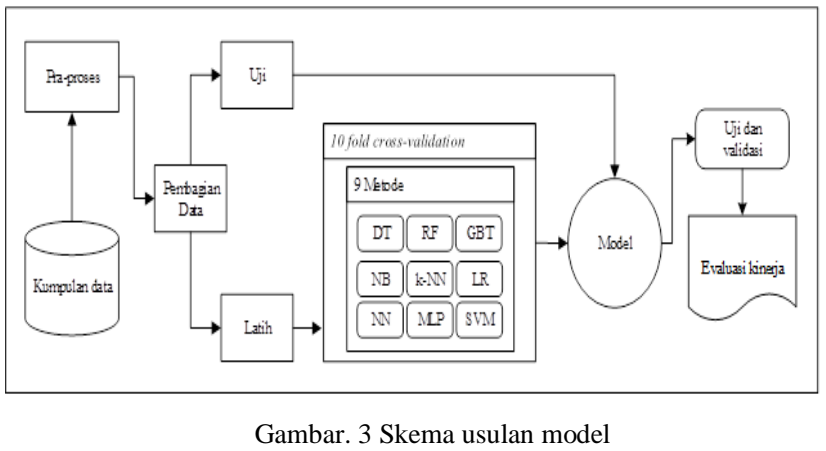

1) Decision Tree: merupakan metode data mining yang dipakai dalam membangun model klasifikasi untuk memprediksi suatu variabel. Model ini dapat menangani sejumlah data yang besar dan rumit tanpa harus merubah struktur parametrik yang rumit. Jika ukuran sampel data cukup besar, data dapat dibagi menjadi datasets training dan datasets validasi [11].

2) Random Forest: sebuah metode yang dapat menganalisa data berdasarkan jenis teknik regresi tertentu. Dengan munculnya daya komputasi yang lebih tersebar luas, Model yang membutuhkan matematika yang lebih kompleks menjadi semakin umum. Terutama di era big data dan machine learning saat ini. Random forest [12] adalah teknik pohon regresi yang menggunakan agregasi bootstrap dan pengacakan prediktor untuk mencapai tingkat akurasi prediksi yang tinggi..

3) Gradient Boosted Tree: metode yang dapat membuat suatu pohon keputusan berdasarkan tingkatan di dalam struktur pohon untuk memperbaiki kesalahan. Metode ini merupakan algoritma prediksi yang secara berurutan menghasilkan model berupa kombinasi linier dari pohon keputusan, dengan menyelesaikan masalah optimasi berdimensi tak hingga [13].

4) Nä̈ve Bayes: metode yang biasa dipakai untuk mengklasifikasi data pada kelas tertentu, kemudian pola tersebut digunakan untuk memperkirakan atau memprediksi sehingga dapat diambil suatu keputusan yang tepat [5].

$$
P(Y \mid X)=\frac{P(Y) * P(X \mid Y)}{P(X)}
$$


5) K-Nearest Neighbor: merupakan metode klasifikasi data yang dapat bekerja secara sederhana daripada algoritma klasifikasi lainnya. KNN merupakan metode klasifikasi yang populer dalam data mining dan statistik karena implementasinya yang sederhana dan kinerja klasifikasi yang signifikan. Algoritma $k$-NN [14] bekerja dengan klasifikasi setiap data agar tidak ditemukan class yang sama dalam proses klasifikasi.

$$
d\left(x_{i}, x_{j}\right)=\sqrt{\sum_{r=1}^{n}\left(a_{r}\left(x_{i}\right)-a_{r}\left(x_{j}\right)\right)^{2}}
$$

6) Logistic Regression: merupakan metode klasifikasi yang sudah terbukti sangat kuat dengan angka probabilitas yang dapat menangani masalah klasifikasi multiclass [15].

$$
\log _{\left(\frac{\pi}{\pi-1}\right)} C 0+C 1 X 1+C 2 X 2+\ldots+C n X n
$$

7) Neural Network: secara sederhana bisa melakukan deteksi lengkap tanpa keraguan bahkan dalam hubungan non-linier yang kompleks antara dependen dan variabel independen berdasarkan jaringan [16].

$$
Y=1+2 X_{1}+3 X_{2}+4 X_{3}
$$

8) Auto Multilayer Perceptron (MLP): metode dengan jaringan saraf tiruan yang merupakan model klasifikasi yang bekerja seperti pada jaringan saraf makhluk hidup [17].

$$
\Delta X=\left[J^{T} J+\mu I\right]^{-} J^{T} e
$$

9) Support Vector Machine: metode klasifikasi, dimana setiap pemodelan memiliki konsep yang matang secara sistematis, metode SVM dapat mengatasi klasifikasi dan regresi baik yang linier mapun yang non linier [18].

$$
\min _{w}=\tau(w)=\frac{1}{2\|w\|^{2}}+C \sum_{i=1}^{l} \varepsilon_{i}
$$

\section{Eksperimen dan Pengujian}

Dalam melakukan tahapan ini, peneliti menggunakan aplikasi Rapidminer sebagai analytics tool. Pada tahapan ini dilakukan eksperimen untuk mendapatkan sebuah hasil dari model (rule) yang digunakan sebagai uji coba pada evaluasi maupun prediksi. Eksperimen dilakukan dengan beberapa model untuk membandingkan dan mencari model terbaik

\section{E. Evaluasi dan Hasil}

Pada tahapan ini, hasil eksperimen akan dibahas model yang telah dihasilkan untuk mengetahui kinerja dari model dalam menentukan capaian yang diperoleh. Standarisasi untuk evaluasi dan prediksi tingkat kesalahan dalam model klasifikasi dengan menggunakan 10 validasi silang (10-fold cross-validation) dan untuk mengevaluasi keakuratan menggunakan akurasi dan dilakukan pengujian dengan uji $t$ untuk mengetahui adanya perbedaan sampel yang berpasangan dan uji Friedman untuk mengetahui peringkat dari rata-rata dari model klasifikasi pada semua kumpulan data (dataset).

TABEL IIIII

CONFUSION MATRIX

\begin{tabular}{|c|c|c|}
\hline \multirow{2}{*}{ Prediksi } & \multicolumn{2}{|c|}{ Aktual } \\
\cline { 2 - 3 } & Tidak & Tepat \\
\hline Tidak & TP & FP \\
\hline Tepat & FN & TN \\
\hline
\end{tabular}

$$
\operatorname{Accuracy}(A C C)=\frac{T P+T N}{T P+F P+F N+T N}
$$

Pada Tabel III merupakan bentuk confusion matrix hasil dari sebuah model yang dibangun, yaitu, True positive (TP) adalah nilai class positif yang diidentifikasikan benar, Kemudian, true negative (TN) adalah nilai class negatif yang diidentifikasikan benar. False positive (FP) adalah nilai class positif yang diidentifikasikan salah, False negative (FN) adalah nilai class negatif yang diidentifikasikan salah. Model dari metode klasifikasi dilakukan pengujian penilaian berdasarkan accuracy [19].

\section{HASIL DAN PEMBAHASAN}

Pada penelitian ini, eksperimen dilakukan menggunakan komputer dengan spesifikasi Intel ${ }^{\circledR}$ Core $^{\mathrm{TM}}$ i3-8130U $2.20 \mathrm{GHz}$ (4 CPUs), 8GB RAM dan sistem operasi Windows 10 64bit dan RapidMiner version 9.7.

TABEL IVV

HASIL CONFUSION MATRIX

\begin{tabular}{|l|c|c|c|c|c|}
\hline \multicolumn{1}{|c|}{ Datasets } & $\boldsymbol{T P}$ & $\boldsymbol{F P}$ & $\boldsymbol{F N}$ & $\boldsymbol{T N}$ & $\boldsymbol{A C C}$ \\
\hline TI-Reg.A & 68 & 26 & 3 & 16 & 74.34 \\
\hline TI-Reg.B & 55 & 17 & 4 & 7 & 74.70 \\
\hline AK-Reg.A & 61 & 6 & 0 & 1 & 91.18 \\
\hline AK-Reg.B & 82 & 8 & 1 & 2 & 90.32 \\
\hline
\end{tabular}

TABEL V

PERBANDINGAN AKURASI

\begin{tabular}{|c|c|c|c|c|c|c|}
\hline Model & $\begin{array}{c}\text { TI- } \\
\text { Reg.A }\end{array}$ & $\begin{array}{c}\text { TI- } \\
\text { Reg.B }\end{array}$ & $\begin{array}{c}\text { AK- } \\
\text { Reg.A }\end{array}$ & $\begin{array}{c}\text { AK- } \\
\text { Reg.B }\end{array}$ & $\begin{array}{c}\text { Rata- } \\
\text { rata }\end{array}$ & Rank \\
\hline DT & 70,80 & 68,67 & 83,82 & 88,17 & 77,87 & 4,13 \\
\hline RF & 74,34 & 74,70 & $\mathbf{9 1 , 1 8}$ & $\mathbf{9 0 , 3 2}$ & $\mathbf{8 2 , 6 3}$ & $\mathbf{8 , 3 8}$ \\
\hline GBT & $\mathbf{7 6 , 9 9}$ & $\mathbf{7 7 , 1 1}$ & 89,71 & 83,87 & 81,92 & 7,00 \\
\hline NB & 64,60 & 60,24 & 86,76 & 79,57 & 72,79 & 1,25 \\
\hline$k$-NN & 69,91 & 68,67 & 89,71 & 88,17 & 79,12 & 4,75 \\
\hline LR & 70,80 & 65,06 & 89,71 & $\mathbf{9 0 , 3 2}$ & 78,97 & 5,75 \\
\hline NN & 71,68 & 63,86 & 89,71 & 89,25 & 78,62 & 5,13 \\
\hline MLP & 68,14 & 63,86 & 89,71 & 89,25 & 77,74 & 4,13 \\
\hline SVM & 66,37 & 66,27 & 89,71 & 89,25 & 77,90 & 4,50 \\
\hline
\end{tabular}




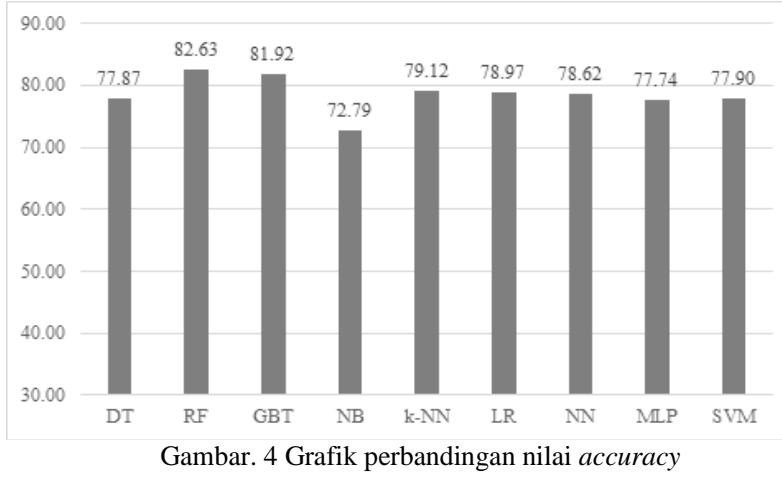

Pada Tabel IV terlihat hasil dari bentuk confusion matrix sebuah model yang dibangun untuk mengetahui kinerja berdasarkan nilai TP, FP, FN dan TN.

Tabel $\mathrm{V}$ menunjukkan perbandingan nilai akurasi dari sembilan model pada empat dataset. Sedangkan Gambar. 4 menunjukkan nilai perbandingan akurasi dalam bentuk grafik, dimana nilai persentase terkecil atau minimum di dalam hasil akurasi adalah $72,79 \%$ dan nilai terbesar atau maksimumnya adalah $82,63 \%$.

Pada hasil eksperimen, ada tujuh model klasifikasi yang berada di bawah nilai rata-rata $80 \%$ dan di atas $70 \%$ yaitu DT, NB, $k$-NN, LR, NN, MLP, dan SVM. Tujuh model tersebut memiliki kinerja yang sama bagus. Namun ada dua model yang memiliki kinerja lebih unggul yaitu model RF dan GBT yang memiliki nilai rata-rata kinerja di atas $80 \%$. Model RF lebih unggul dibandingkan dengan model GBT pada penerapan dataset AK-Reg.A dan AK-Reg.B dengan masing-masing nilai di atas $90 \%$. Namun model RF tidak sebagus model GBT pada penerapan dataset TI-Reg.A dan TI-Reg.B.

Dalam penelitian ini, dilakukan pengujian hipotesis menggunakan uji $t$ sampel berpasangan. Menurut [20] uji statistik ( $t$-Test) dilakukan dengan menggunakan nilai taraf signifikan 5\%. Suatu hipotesis diterima atau ditolak berdasarkan dengan aturan, jika nilai $p>0,05$, maka $\mathrm{H}_{0}$ diterima dan $\mathrm{H}_{\mathrm{a}}$ ditolak, jika nilai $p<0,05$, maka $\mathrm{H}_{0}$ ditolak dan $\mathrm{H}_{\mathrm{a}}$ diterima. Pada tahap pengujian, t-Test digunakan untuk menguji sembilan model klasifikasi, dimana ketika pengujian, dikatakan sebagai hasil uji yang signifikan apabila mendapatkan nilai $p \leq 0,05$.

TABEL VI

Uji SEMBILAN MODEL PADA PRODI TI-REg A

\begin{tabular}{|c|c|c|c|c|c|c|c|c|c|}
\hline Model & DT & RF & GBT & NB & $\boldsymbol{k}$-NN & LR & NN & MLP & SVM \\
\hline DT & & 0,326 & 0,921 & 0,074 & 0,350 & 0,551 & 0,907 & 0,934 & 0,175 \\
\hline RF & & & 0,533 & 0,294 & 0,055 & 0,088 & 0,337 & 0,546 & 0,554 \\
\hline GBT & & & 0,199 & 0,408 & 0,582 & 0,987 & 0,992 & 0,326 \\
\hline NB & & & & $\mathbf{0 , 0 1 0}$ & $\mathbf{0 , 0 1 4}$ & 0,066 & 0,216 & 0,732 \\
\hline$k$-NN & & & & & 0,668 & 0,264 & 0,436 & $\mathbf{0 , 0 3 3}$ \\
\hline LR & & & & & & & 0,435 & 0,610 & 0,050 \\
\hline NN & & & & & & & 0,997 & 0,175 \\
\hline MLP & & & & & & & & 0,342 \\
\hline SVM & & & & & & & & & \\
\hline
\end{tabular}

TABEL VII

UjI SEMBILAN MODEL PADA PRODI TI-REg B

\begin{tabular}{|c|c|c|c|c|c|c|c|c|c|}
\hline Model & DT & RF & GBT & NB & k-NN & LR & NN & MLP & SVM \\
\hline DT & & 0,879 & 0,643 & 0,568 & 0,784 & 0,792 & 0,470 & 0,155 & 0,993 \\
\hline RF & & & 0,756 & 0,707 & 0,707 & 0,902 & 0,410 & 0,220 & 0,882 \\
\hline GBT & & & 1,000 & 0,551 & 0,869 & 0,292 & 0,392 & 0,659 \\
\hline NB & & & & 0,510 & 0,847 & 0,224 & 0,302 & 0,599 \\
\hline k-NN & & & & & 0,654 & 0,768 & 0,203 & 0,797 \\
\hline LR & & & & & & & 0,386 & 0,323 & 0,799 \\
\hline NN & & & & & & & 0,064 & 0,501 \\
\hline MLP & & & & & & & & & 0,184 \\
\hline SVM & & & & & & & & & \\
\hline
\end{tabular}

TABEL VIII

UjI SEMBILAN MODEL PADA PRODI AK-REg A

\begin{tabular}{|c|c|c|c|c|c|c|c|c|c|}
\hline Model & DT & RF & GBT & NB & $\boldsymbol{k}$-NN & LR & NN & MLP & SVM \\
\hline DT & & 0,836 & 0,408 & 0,067 & 0,412 & 0,248 & 0,248 & 0,106 & 0,248 \\
\hline RF & & & 0,308 & $\mathbf{0 , 0 2 7}$ & 0,485 & 0,270 & 0,270 & 0,096 & 0,270 \\
\hline GBT & & & & 0,567 & 0,149 & 0,094 & 0,094 & $\mathbf{0 , 0 5 0}$ & 0,094 \\
\hline NB & & & & $\mathbf{0 , 0 0 6}$ & $\mathbf{0 , 0 0 1}$ & $\mathbf{0 , 0 0 1}$ & $\mathbf{0 , 0 0 0}$ & $\mathbf{0 , 0 0 1}$ \\
\hline$k$-NN & & & & & 0,791 & 0,791 & 0,387 & 0,791 \\
\hline LR & & & & & & & 1,000 & 0,363 & 1,000 \\
\hline NN & & & & & & & & 0,363 & 1,000 \\
\hline MLP & & & & & & & & & 0,363 \\
\hline SVM & & & & & & & & & \\
\hline
\end{tabular}

TABEL IX

Uji Sembilan Model Pada PRodi AK-Reg B

\begin{tabular}{|c|c|c|c|c|c|c|c|c|c|}
\hline Model & DT & RF & GBT & NB & $\boldsymbol{k}$-NN & LR & NN & MLP & SVM \\
\hline DT & & 0,489 & 0,749 & 0,131 & 0,058 & 0,148 & $\mathbf{0 , 0 3 3}$ & 0,431 & $\mathbf{0 , 0 3 3}$ \\
\hline RF & & & 0,381 & 0,063 & 0,130 & 0,353 & 0,068 & 0,827 & 0,068 \\
\hline GBT & & & & 0,219 & 0,075 & 0,149 & 0,050 & 0,340 & 0,050 \\
\hline NB & & & & $\mathbf{0 , 0 1 8}$ & $\mathbf{0 , 0 2 9}$ & $\mathbf{0 , 0 1 4}$ & 0,059 & $\mathbf{0 , 0 1 4}$ \\
\hline$k$-NN & & & & & 0,512 & 0,730 & 0,316 & 0,730 \\
\hline LR & & & & & & & 0,316 & 0,600 & 0,316 \\
\hline NN & & & & & & & & 0,211 & 1,000 \\
\hline MLP & & & & & & & & & 0,211 \\
\hline SVM & & & & & & & & \\
\hline
\end{tabular}

Dari setiap tabel uji $t$ sembilan model yang sudah dihasilkan, maka untuk nilai uji $t$ memiliki aturan, yaitu, apabila nilai $p<0,05$ terdapat perbedaan pada taraf signifikan yaitu 5\%, dan apabila nilai $p>0,05$, maka tidak ada perbedaan antara sebelum dan sesudah. Pada Tabel VI, ada tiga perbedaan yang signifikan yaitu NB dengan $k$-NN dengan nilai 0,010 dan LR sebesar 0,014, sedangkan $k$-NN dengan SVM sebesar 0,033. Pada Tabel VII, dari sembilan metode tidak ada perbedaan yang signifikan dengan nilai $p>$ 0,05 . Pada Tabel VIII, ada tujuh perbedaan yang signifikan, diantaranya yaitu RF dengan NB nilainya sebesar 0,027 , kemudian GBT dengan MLP 0,050, selanjutnya NB 
dengan $k$-NN 0,006, LR 0,001, NN 0,001, MLP 0,000, dan SVM 0,001. Pada Tabel IX, ada enam perbedaan yang terlihat yaitu antara DT dan NN sebesar 0,033 dan SVM 0,033 , kemudian NB dengan $k$-NN 0,018, LR 0,029, NN 0,014, dan SVM 0,014.

Uji Friedman juga digunakan untuk memberikan peringkat (rank) rata-rata dari setiap model klasifikasi pada semua dataset dan juga untuk menguji signifikan perbedaan akurasi diantara sembilan model. Berdasarkan hasil uji Friedman pada Tabel $\mathrm{V}$, peringkat tertinggi pada model klasifikasi RF dengan nilai rata-rata peringkat sebesar 8,38. Nilai Asymp. Sig. diperoleh dari hasil signifikan dengan nilai sebesar 0,021 lebih kecil dari 0,05 dan dinyatakan sebagai adanya perbedaan nilai rata-rata.

\section{KESIMPULAN}

Pada penelitian ini, disampaikan laporan mengenai perbandingan evaluasi kinerja akademik mahasiswa, dimana model klasifikasi yang dibangun menggunakan sembilan metode. Dari hasil eksperimen dan analisis, ada tujuh model klasifikasi yang sama bagus yaitu DT, NB, $k$ NN, LR, NN, MLP, dan SVM. Namun, pada model lain ada dua model yang lebih unggul dibandingkan tujuh model tersebut yaitu model RF dan GBT. Kedua model tersebut memiliki kinerja model yang sebanding. Namun, model RF lebih unggul dibandingkan dengan model GBT pada hasil nilai rata-rata. Disisi lain, model RF memiliki keunggulan pada evaluasi menggunakan dataset AK-Reg.A dan AKReg.B dengan nilai masing-masing di atas $90 \%$. Sedangkan, model GBT unggulan pada evaluasi menggunakan dataset TI-Reg.A dan TI-Reg.B dengan nilai masing-masing di atas $70 \%$. Berdasarkan uji Friedman, bahwa model RF memiliki peringkat tertinggi dengan nilai rata-rata peringkat sebesar 8,38. Jadi, dapat disimpulkan bahwa perbandingan pada sembilan model klasifikasi yang dievaluasi berdasarkan empat dataset, model random forest unggul dan dapat diandalkan. Dalam hal ini, model random forest dapat dijadikan solusi untuk evaluasi kinerja akademik mahasiswa.

\section{UCAPAN TERIMA KASIH / ACKNOWLEDGMENT}

Terima kasih kepada semua pihak yang telah memberikan dukungan, terutama peneliti ucapkan terimakasih atas bantuan berupa dana Hibah dari Direktorat Jendral Penguatan Riset dan Pengembangan, Kementrian Riset Teknologi dan Perguruan Tinggi dan tentunya juga kepada Universitas Pamulang yang telah memberikan kontribusi kepada penelitian ini.

\section{REFERENSI}

[1] C. Romero and S. Ventura, "Educational data mining and learning analytics: An updated survey," WIREs Data Min. Knowl. Discov., vol. 10, no. 3, pp. 1-21, May 2020, doi: 10.1002/widm.1355.

[2] A. Bisri and R. Rachmatika, "Integrasi Gradient Boosted Trees dengan SMOTE dan Bagging untuk Deteksi Kelulusan Mahasiswa,' J. Nas. Tek. Elektro dan Teknol. Inf., 2019, doi: 10.22146/jnteti.v8i4.529.

[3] "Penerapan Adaboost untuk Penyelesaian Ketidakseimbangan Kelas pada Penentuan Kelulusan Mahasiswa dengan Metode Decision Tree," J. Intell. Syst., 2015.

[4] A. Azahari, Y. Yulindawati, D. Rosita, and S. Mallala, "Komparasi Data Mining Naive Bayes dan Neural Network memprediksi Masa Studi Mahasiswa S1," J. Teknol. Inf. dan Ilmu Komput., vol. 7, no. 3, p. 443, May 2020, doi: 10.25126/jtiik.2020732093.

[5] A. M. Shahiri, W. Husain, and N. A. Rashid, "A Review on Predicting Student's Performance Using Data Mining Techniques," 2015, doi: 10.1016/j.procs.2015.12.157.

[6] B. K. Francis and S. S. Babu, "Predicting Academic Performance of Students Using a Hybrid Data Mining Approach," J. Med. Syst., 2019, doi: 10.1007/s10916-019-1295-4.

[7] B. Guo, R. Zhang, G. Xu, C. Shi, and L. Yang, "Predicting Students Performance in Educational Data Mining," 2016, doi: 10.1109/ISET.2015.33.

[8] C. Jalota and R. Agrawal, "Analysis of Educational Data Mining using Classification," 2019, doi: 10.1109/COMITCon.2019.8862214.

[9] N. A. Yassein, R. G. M Helali, and S. B. Mohomad, "Predicting Student Academic Performance in KSA using Data Mining Techniques," J. Inf. Technol. Softw. Eng., 2017, doi: 10.4172/21657866.1000213.

[10] A. U. Khasanah and Harwati, "A Comparative Study to Predict Student's Performance Using Educational Data Mining Techniques," 2017, doi: 10.1088/1757-899X/215/1/012036.

[11] Y. Y. Song and Y. Lu, "Decision tree methods: applications for classification and prediction," Shanghai Arch. Psychiatry, 2015, doi: 10.11919/j.issn.1002-0829.215044.

[12] S. J. Rigatti, "Random Forest," J. Insur. Med., 2017, doi: 10.17849/insm-47-01-31-39.1.

[13] G. Biau, B. Cadre, and L. Rouvière, "Accelerated gradient boosting," Mach. Learn., 2019, doi: 10.1007/s10994-019-05787-1.

[14] S. Zhang, X. Li, M. Zong, X. Zhu, and R. Wang, "Efficient kNN classification with different numbers of nearest neighbors," IEEE Trans. Neural Networks Learn. Syst., 2018, doi: 10.1109/TNNLS.2017.2673241.

[15] E. Christodoulou, J. Ma, G. S. Collins, E. W. Steyerberg, J. Y. Verbakel, and B. Van Calster, "A systematic review shows no performance benefit of machine learning over logistic regression for clinical prediction models," Journal of Clinical Epidemiology. 2019, doi: 10.1016/j.jclinepi.2019.02.004.

[16] S. Liu et al., "Cambricon: An Instruction Set Architecture for Neural Networks,” 2016, doi: 10.1109/ISCA.2016.42.

[17] C. Zhang et al., "A hybrid MLP-CNN classifier for very fine resolution remotely sensed image classification," ISPRS $J$. Photogramm. Remote Sens., 2018, doi: 10.1016/j.isprsjprs.2017.07.014.

[18] D. A. Pisner and D. M. Schnyer, "Support vector machine," in Machine Learning: Methods and Applications to Brain Disorders, 2019.

[19] S. ElAtia, D. Ipperciel, and O. R. Zaïane, Data Mining And Learning Analytics: Applications in Educational Research. 2016.

[20] I. H. Witten, E. Frank, M. A. Hall, and C. J. Pal, Data Mining: Practical Machine Learning Tools and Techniques. 2016. 